\title{
Gender and technology in free play in Swedish early childhood education
}

\author{
Jonas Hallström, Helene Elvstrand and Kristina Hellberg
}

Linköping University Post Print

Tweet

N.B.: When citing this work, cite the original article.

The original publication is available at www.springerlink.com:

Jonas Hallström, Helene Elvstrand and Kristina Hellberg, Gender and technology in free play in Swedish early childhood education, 2015, International journal of technology and design education, (25), 2, 137-149.

http://dx.doi.org/10.1007/s10798-014-9274-Z

Copyright: Springer Verlag (Germany)

http://www.springerlink.com/?MUD=MP

Postprint available at: Linköping University Electronic Press

http://urn.kb.se/resolve?urn=urn:nbn:se:liu:diva-117417 
Gender and technology in free play in Swedish early childhood education

Jonas Hallström*, Helene Elvstrand* and Kristina Hellberg **

*Dept. of Social and Welfare Studies

Linköping University

S-601 74 Norrköping, Sweden

e-mail: jonas.hallstrom@liu.se

**Dept. of Behavioural Sciences \& Learning

Linköping University

S-581 83 Linköping, Sweden 


\title{
Gender and technology in free play in Swedish early childhood education
}

\begin{abstract}
In the new Swedish curriculum for the preschool (2010) technology education is emphasized as one of the most significant pedagogical areas to work with. The aim of this article is to investigate how girls and boys explore and learn technology as well as how their teachers frame this in free play in two Swedish preschools. The study is inspired by an ethnographic approach and is based on qualitative data collected through video-taped observations and informal talk with children and teachers in two preschools. It is concluded that girls and boys learn to approach and handle technology differently, thereby confirming rather than dissolving gender boundaries. The girls more often have a special purpose in building something they need in their play, that is, they mostly engage in technological construction as a sideline. The boys, on the other hand, more often award technological construction a central part in their play; building is an end in itself. Teachers are not so active in supporting free play involving technology among the older children, nor in giving boys and girls equal opportunities to explore and use material and toys which are not gender-stereotyped. One important implication is that in-service education needs to address not only experiments and construction but also gender issues and how teachers can create equal opportunities for boys and girls in the free play.
\end{abstract}

Keywords: preschool; technology education; free play; gender; Sweden

There is a scarcity of educational research concerning the learning of science and technology in the early years of schooling, particularly in the preschool/kindergarten setting. This is partly due to the fact that many countries do not have a science and/or technology curriculum for the very early years, but there is also a lack of teaching due to unsatisfactory teacher education and teaching materials. Tu (2006), for instance, investigated science environments in 20 preschool classrooms in the USA. He concludes that preschool teachers mostly organised activities that were unrelated to science but that around $13 \%$ of the activities were related either to formal or informal science education. According to Tu this low degree of science education in preschools both has to do with lack of science-related 
materials in the classrooms and teachers' unawareness of how to create science activities in daily preschool life. ${ }^{1}$

In recent years research in science and technology education has begun incorporating studies of preschools. As regards the few studies in technology education researchers conclude that technology is largely missing in preschool activities, but that children need to be introduced to it early on in order for them to utilize their natural curiosity and to gain selfconfidence concerning technology (see, for example, Stables, 1997; Axell, 2013). At the same time gender stereotypes are formed at a very early age, especially in relation to technology. Thus in order to become technologically literate citizens (Pearson \& Young, 2002) children need to be introduced to technology as early as possible but at the same time this also reinforces gendered patterns of behavior among girls and boys, which becomes a dilemma for teachers as well as curriculum developers.

In this article we take this dilemma as a starting point. The aim is to investigate how girls and boys explore and learn technology as well as how their teachers frame this in free play in two Swedish preschools. The study is inspired by an ethnographic approach in a grounded theory tradition, and is based on qualitative data collected through video-taped observations and informal talk with children (primarily three to six years old) and teachers in two different Swedish preschools. ${ }^{2}$ We begin with a research overview that relates to the aforementioned problematic and thus connects play and gender to the learning of technology in early childhood. These studies concern primarily preschools/kindergartens but also schools in some cases, since children aged three to six years can be either in the preschool or the school depending on country and school system. ${ }^{3}$

\section{Technology education and play in early childhood}

Fleer (2000) claims that there is little knowledge about how small children work when in technological learning contexts. In her article she presents a pilot study about the planning, making and appraising of technological activities by children three to five years old in a child

\footnotetext{
${ }^{1}$ The research on which this article is based has also partly provided material for Elvstrand et al (2012).

${ }^{2}$ Swedish preschools have two distinct teacher categories, the university-educated pedagoger or nowadays more commonly förskollärare, and the child minders (barnskötare) without university education. Since we have not analysed them separately we choose to label both categories as preschool teachers.

${ }^{3}$ For a recent, important overview of primary technology education, see Benson \& Lunt (2011).
} 
care centre in the Australian Capital Territory. The study indicates that children as young as three years old can engage in oral and visual planning when making things from materials, although it was difficult for most of them to use their plans for making constructions; the making did occur but the children often copied each other rather than following their own designs (Fleer, 2000. Cf. Fleer, 1992; 1999; Hope, 2000). Milne (2013) is of the view that children at the age of five can be taught some design capabilities, but that it could be further enhanced by taking note of the focused but less structured practices of early childhood with a greater focus on child initiated play and fewer constraints posed by artificially posed tasks' ( $p$. 11). Carr (2000) is of a similar view and promotes a preschool environment with 'plenty of time for children to explore their own metaphors and interests' (p. 76).

Turja et al (2009) also emphasize the importance of the child-initiated play. They present an overview of early childhood education curricula in six countries, and they conclude that the curricula do not offer much guidance for technology education in the early years. However, there are activities that can be utilized to boost technology education: 'Play is highlighted as a fundamental way of learning seldom studied in the context of technology education' (Turja et al, 2009, p. 353). The authors assert that activities associated with technology might be transformed into roles that children can try out when playing - for instance, the roles of designer/inventor, manufacturer, mender, consumer/user etc. Turja et al (2009) also expound on various types of play, of which the best one for technology education seems to be the functional play where "children acquire knowledge of objects, materials and physical phenomena, and learn to master the use of tools and techniques through explorations and rehearsals' (p. 360). In short, it becomes possible for children to practice advanced technological activities and roles through creative play.

Parker-Rees (1997) suggests that there are structural similarities between free play and design and technology activities, since they both help promoting creative, critical and playful thinking when solving problems. Play can also assist in developing children's language by helping them relate abstract concepts and ideas to technological objects that they use in playful and creative ways. Furthermore, free play can stimulate the ability to form images in the mind's eye, a kind of cognitive modelling important in design and technology activities (Parker-Rees, 1997). One can thus conclude that technology can be learnt in free play in various ways, from technological role play to language acquisition and concept learning to cognitive modelling.

\section{Technology and gender in early childhood}


The preschool is an institution where gender plays a central role, be it in play, teaching or other preschool activities. In gender studies it is common knowledge that gender stereotypes are commonplace among children in the preschool and that play and the use of play materials and technologies are likewise gender-stereotyped (e.g. MacNaughton, 2006; Ärlemalm-Hagsér \& Pramling Samuelsson, 2009). Freeman (2007) interviewed preschoolers of three and five years old and asked them to categorize toys such as skateboards, tea sets, motorcycles, dolls, gowns etc. as 'girl toys' and 'boy toys' and which toys they thought their parents would want them to play with. The study also included the parents' self-reported attitudes to gender-related behaviour. Freeman concludes that the children constructed stereotypical definitions of which toys each sex should play with. The children believed that cross-gender choices would be less well received with their parents, although the parents claimed to be largely gender-neutral (Freeman, 2007). Technology in the form of toys thus helps children to construct their gender identity at a very early age, as early as between three and five years old.

Turja et al (2009) also claim that gender stereotypes are created as early as the age of three, which can be seen in the preschool when boys choose cars or typical male roles and girls pick dolls and typical female roles. Boys and girls should therefore, as far as possible, have equal access to activities and material that are gender-neutral. Building and construction, either organised or in free play, should also be made in social contexts that do not discourage boys or girls from participating (Turja et al, 2009, p. 363; cf. Nisbet, Pendergast \& Reynolds, 1998, p. 13-15).

Sullivan \& Bers (2013) wanted to investigate whether the introduction of a robotics program to girls as well as boys already in kindergarten would somehow counteract typical male outperformance of girls in robotics and programming. They conclude that although the boys had a higher mean score on around half of the tasks, few of the differences were statistically significant; both sexes were able to complete the program with good results (Sullivan \& Bers, 2013).

Mawson (2010) discusses the changing conception of the word 'technology' of seven children during their first six years in school (ages five to ten) in New Zealand. Mawson shows that the girls found it more difficult to pin down what technology is compared to the boys. It is not clear why the girls were more uncertain in their understanding of the concept, but one explanation, according to Mawson, could be that the girls seemed to have a broader, more contextualized view of technology. They seemed to view technology in a wider context than the questions they had to deal with in the study. On the other hand, the girls had a more narrow conception in the sense that they did not see technology as planning to 'develop new 
things' to the same extent as the boys, while both sexes ageed that 'technology is making plans to solve problems' (Mawson, 2010, p. 3-8). The children generally had a positive attitude towards technology, particularly the boys, but especially the girls were ambivalent regarding the value of technology for society (Mawson, 2010, p. 10; Cf. Mawson, 2007).

In sum, gender-related behaviour in relation to technology seems to be the most stereotypical in early childhood, that is, ages three to five. Gender differences continue even as children grow older, however, although they are not as clear-cut and thereby involve various contradictions that cannot be reduced to gender differences.

\section{Theoretical perspectives and methodology}

The study takes as one of its starting-points the framework of the sociology of childhood (James \& Prout, 1990). One assumption in the sociology of childhood is that childhood is understood as a social construction. This means that childhood as a phenomenon varies over time and in different contexts. In this perspective it is also important that childhood cannot be separated from other variables like class, ethnicity and gender. It is also crucial to study children's relations with each other and to study children's living conditions in their own right (Prout \& James, 1997). This also means that even young children are to be taken seriously in technology education; children play an active role when engaging with science and technology and they do it in their own way(s). As a way of highlighting this in the analysis, we reformulate Koch et al's (2011) term childish science as childish technology, since we focus on how children develop their own sense-making through specific cultures, social relations and rationalities and how specific materials and technologies represent, communicate and translate knowledge in relation to children's practices (Koch, Sørensen \& Levidow, 2011).

The study is based on qualitative data collected by video-taped observations of and informal talk with teachers and children inspired by an ethnographic approach (Hammersley \& Atkinson, 1995), in two preschools in Sweden. Contact was established with the headmasters of these preschools according to a strategy selection (Bryman, 2001). Both preschools receive children from one to six years old. Neither of them has any special pedagogical ideology, except for the general directions laid out in the Swedish preschool curriculum of 2010 where science and technology are emphasized content (Skolverket, 2010). The staff consists of preschool teachers working in teams. The preschools are located in the south of Sweden, in one of the larger Swedish municipalities - kommun, an administrative division consisting of both rural and urban areas. The City Council of the 
municipality has decided that one of the central areas to develop in all the preschools is science and technology. Preschool one is located in a small village in the countryside and consists of three different departments with a total of 120 children. Preschool one has recently started a project where technology in daily life is focussed, and one of the teachers has the specific task to work with technology both directly with the children and to increase the other teachers' knowledge about technology. Preschool two is located in an urban area and consists of some 20 children in each of its two departments, in sum 45 children. Here the teachers have a more general responsibility to work with technology together with the children, in line with the municipal regulations and the curriculum.

The focus of the observations was on the children's free play with technology, both in the preschool building and outdoors. The notion of 'free play' is considered crucial in the Swedish context, not only because it makes up such a large part of the preschool schedule but also since it denotes a far-reaching freedom of children to decide what they want to do in their play (Löfdahl, 2002). However, the children also interact with the preschool teachers, as the latter support and supervise the children in different ways and to various degrees during the play. The observations consequently both included individual activities and collective ones where children and preschool teachers were involved together.

The study is based on fieldwork on nine occasions of two to six hours each in the two preschools. In preschool one we conducted observations in two of the departments (38 children altogether), but during the observation outdoors children from other departments were also involved. Both preschool one and two work with mixed-age groups. This means that the children on some occasions play together in a range of ages, but on other occasions they are divided into homogeneous age groups. In our observations we mainly followed children aged between three and six years old. The distribution between girls and boys was quite equal in this age span.

The study was inspired by a Grounded Theory approach (Charmaz, 2007), that is, we tried to carry out as unprejudiced observations as possible. The overall problematic in the beginning of the study was how technology was manifested in free play in the preschools, but gradually we came to zoom in on how children explore technology as well as the role of the teachers in this. In the analysis of data the field notes were coded and, after repeated readings, the codes were finally clustered into categories. In this process we developed the aim into how girls and boys explore and learn technology as well as how their teachers frame this in free play. Important categories crystallised such as construction play, purpose of construction, gender differences, self-confidence and teachers' activity. In the discussion these categories 
are related to other research as well as theoretical perspectives. We also draw conclusions and suggest implications based on the discussion.

Ethical considerations have been important during the whole research process, in getting access to the field as well as in relations during the fieldwork (Roberts, 2008; Alderson, 2000). We followed the ethical principles set up by the Swedish Research Council (Vetenskapsrådet, 2013). Children, parents and preschool teachers have been informed about and have consented to the study. In relation to the children we have also asked them or tried to interpret their body language before observing/video recording, so as not to infringe on their integrity. All the names of children and teachers that appear in the results section are fictitious.

\section{Results}

\section{Children's use of technology in free play outdoors and indoors}

The observed situations show that children use technology in their daily life in the preschool, both in situations which are planned as technology activities by the preschool teachers and in their free play. In both preschools the children have access to traditional construction material such as Lego and wooden railways indoors and battens, ropes, cans and pipes outdoors. The teachers have also actively gathered different natural construction materials not originally designed for children's play such as sticks and cones, aimed at encouraging construction play. Children of all ages are quite free to make their own choices regarding what kind of material they want to play with. The youngest children naturally have some restrictions for safety reasons, for example, they are not allowed to play with small pieces of Lego.

When the children play outdoors the central place for relating to technology is the sandbox. Children make sand cakes, they construct roads and transport different kinds of materials on these roads. The sandbox is a place which attracts children of all ages in the preschool. When the children play indoors both boys and girls are occupied with different kinds of construction play.

How children handle technology in their indoor play depends on many factors such as their age, what they like to play but also what kind of play is possible in the preschool. One of the preschools has boxes where they put different kinds of material with the aim of inspiring children to change roles in their play; in one box there can be tools for a barber, in another box small cars. These boxes can inspire children to a different kind of play but they can at 
the same time function as obstacles to trans-boundary play, for instance, when it comes to gender. The institutional conditions in the preschools in terms of how space and time are organised are also important factors. For example, in the urban preschool the play is freer in that the children move freely between different rooms and they can even bring indoor toys outside, while in the other the play is more organised and restricted to a certain area.

At a group level the analysis shows that both what kind of play the children are engaged in and what kind of toys the children use are gendered. For example, boys play to a higher degree with toys that can be categorized as typical toys for boys - cars, cranes etc. The gender differences in children's play are much more pronounced among the oldest children in the data, that is, the five to six-year-olds. These children are to a higher degree organised in girls' versus boys' groups and thereby girls' versus boys' play (cf. Freeman, 2007). These patterns are obvious both indoors and outdoors when children are free to organise their own play. When the teachers organise activities they always mix girls and boys.

\section{Girls and boys in construction play}

Construction play is a common activity among the children in the study. The empirical data indicates that there is a gender difference regarding how children use construction in their play and what purpose construction has for them. The observations show that boys more often construct things where the technological process or activity is central:

David and Hampus [five-year-old boys] are playing in the preschool yard. They are building a little house together with the help of battens. They discuss and negotiate how to make it as strong as possible. They spend much time constructing. During one sequence they are building the roof. David is at the top and Hampus ... gives him battens. When the roof has been laid the house is finished (field notes).

The above situation shows that for David and Hampus the activity to construct is the main purpose of the play. Construction can be seen as the play itself; the boys are focused upon making the construction as solid as possible, which is why during the play they negotiate about the best building methods. In their play they also use advanced language for their age. For instance, Hampus asks David for a drill pin (borrstift). In another situation we can see how a group of girls 'do technology' in their play:

Four girls of different ages [three to five years old] are playing with battens in the preschool yard. They want to make a sloping chute down which they can slide [rutschbana] and come up with the idea that they can angle the battens against the fence. They then slide down the chute made up of the angled battens (field notes). 
Malin and Ronja [four-year-old girls] are playing with battens. They use them as tools in making letters (field notes).

In another situation indoors, free play is going on in a room equipped with construction material. Two four-year-old boys are playing with building blocks while a girl of the same age is playing with a toy farm. The boys have emptied the box of building blocks onto the floor and thereafter they have built a road system on which they are driving racing cars:

'No, let it drive here,' says one of them.

'Let's alter the roads to make driving better and faster,' says the other.

'Then we have to break the roads' (field notes).

The two boys tear apart the road system that they have built. They start all over and build a new and, according to them, improved road system. While they are doing this they also talk with each other about how to place the blocks for the roads to be good to drive on. When they drive their cars on the new block-made road it breaks once again. This means that they have to continuously mend and reconstruct their roads during play.

The girl, on the other hand, is building a fence to make a pen around the farm. When she is done she places various animals such as horses and cows in the pen. She lets the animals gallop and jump in the pen and she also gives them food and water.

'Right, now you have got both hay and water,' says the girl (field notes).

The girl is playing with the animals in the pen for a while. She is satisfied with the fence she built originally and thus makes no changes or adjustments to the construction as long as the play lasts.

Our interpretation of the above field notes is that both girls and boys engage in problem solving and construction in their free play. However, for boys the construction is at the centre of their play. Either they work hard on a design such as the house or when they are finished they tear the design down to start all over again, in order to improve it and thereby the play (cf. the roads). The girls, on the other hand, to a greater extent build or construct something with another end in mind - the play - which can be seen both in the case of the letters and the farm.

\section{Girls' lack of self-confidence}


Generally, boys and girls have positive feelings towards technology, although boys seem to be a little more interested in technology than girls (cf., for example, de Vries, 2005; Mawson, 2010). In our observations, however, we can see that girls and boys approach technology in different ways as regards self-confidence:

Some four- and five-year-old children work with volcanoes as a theme. The work consists of different tasks, of which the first one is to draw a volcano. The next task is to do an experiment to see how a volcano works. They first make a model of it. Then the preschool teacher asks the children if they want to put baking powder in the volcano. The children then act in different ways in relation to their gender. The boys actively tell the teacher what they want and they also show it with their body language [...] The girls think that it is scary and change places so that they can sit at a distance from the volcano (field notes).

In this empirical example the gender differences between the children are very clear. There are no differences when the children are drawing and making models in the beginning of the activity. However, during the experiment, which is quite a new situation for the children, it is the boys who are the most active while the girls distance themselves. We cannot know for certain why the girls do this. It is conceivable that it has to do with a lower degree of selfconfidence than boys, but may also be for safety reasons. We have seen the same difference in self-confidence on other occasions as well, for example, boys seem over all more self-confident when presenting themselves. They are also more eager to try something new, especially in relation to technology and science activities such as the above which seem to be more familiar for many of the them.

The issue of girls' self-confidence also manifests itself in other cases, for instance, when they take on the role of helping boys:

A group of children are playing in the construction room. The room is equipped with different kinds of materials with the purpose of stimulating construction games. Two boys [five years old] are playing with blocks. They are talking with each other and decide to build a tower as high as possible. Amanda [five years old] is looking at the boys' play but she does not touch or play with the blocks herself. After a while she starts to serve one of the boys with blocks. For several minutes the girl is watching the construction play. She never tries to build herself but gives blocks to the boys (field notes).

There is no way of knowing the exact reason for the girl's behaviour. Turja et al (2009) claim that girls generally have a lower self-confidence when it comes to activities which are seen as stereotypically male. Although building a tower with blocks is not a stereotypically male 
activity, it still seems likely that she does not dare to enter the play on the same terms as the boys; in this situation she therefore becomes a "helper" to the boys.

\section{Preschool teachers' understanding of gender}

The preschool teachers' understanding of gender is contradictory. Some say that they see no difference between the sexes concerning the free play in relation to technology. This is in line with their overall view of gender: 'In technology there is no difference between the sexes until we as adults impose our own values' (Nathalie, preschool teacher). Other teachers are of the view that they can detect a difference between what boys and girls play with and how they do it (cf. Turja et al, 2009). They exemplify with the fact that boys more often build garages and roads while girls construct objects to do with, for instance, farming. Preschool teacher Eva says:

'And then I feel that, how should you deal with this, because the boys tend to play together. The boys build and design a lot ... how can we make it more interesting for the girls? Outdoors it is easier to find solutions, take for instance the sand box ... In outdoor activities gender makes less difference ... .' (field notes).

In the above quote the teacher describes how technology is easily connected to boys and masculinity, at least when the children play indoors (although we have seen this phenomenon even outdoors). Nathalie also acknowledges this:

'Since everything is technology then girls also deal with technology, but girls devote themselves to specific activities. There is no buffet [of technological activities] for them' (field notes).

\section{Preschool teachers' interaction - active or passive}

How teachers interact with the children during free play in relation to technology have two main approaches - active or passive interaction:

It is early morning in the preschool and the children are playing in the construction room. Two boys [three and a half years old] are constructing a hut and Albin [three years old] tries to attach a blanket to the bookshelf. He wants to use the shelf as a nook but the blanket falls down several times. One of the teachers asks Albin: 'What do you think you can use to get the blanket to attach?' Albin answers: 'Take a clamp.' The teacher confirms him by saying: 'Yes, we can do that. Do you want me to fetch a 
clamp?' Albin says: 'Fetch clamp.' The teacher then goes to another room to fetch a clamp and she helps Albin to attach it (field notes).

Although the play was initiated by the boys, in the transcript described above the preschool teacher actively helps Albin to construct a more solid hut. She gets involved in the work by asking Albin what he needs for his construction and then she fetches it. In the data there are also other situations where the teachers are involved in the children's play and therefore help them either practically to construct something or verbally by telling them how to solve a problem:

The children are playing outdoors. In the yard there is a big chestnut tree and the ground is full of chestnuts that the children are collecting. Some children get the idea to crush the chestnuts and they start to stamp on them. Nothing happens, the chestnuts remain whole. One of the teachers asks the children how they can break the chestnuts and together they conclude that they can use a tool. The teacher then fetches a small batten with which the children can crush the chestnuts (field notes).

In one of the preschools they have something they call 'technology play', which is an activity for the youngest children who are one to two years old. The activity takes place half an hour per week and during this time the teachers sit on the floor among the children and encourage them to build with Lego blocks or wooden blocks. The teachers play an active role during this activity, and they help and assist the children in constructing, for example, different buildings such as towers.

During a significant time of what can be categorized as free play the children play without the involvement of teachers. This is a particularly characteristic part of the play, taking part among the older children and also more commonly when children play outdoors:

The children [two to six years old] are playing on a slab of stone. They want to make a chute for water to run downhill. They do not have any water nearby so they try to find it elsewhere; they find a puddle and then they carry water with a spade to the slab of stone. It is difficult to climb whilst carrying water with the spade, so most of the water has escaped before they can pour it in the chute. One child says that he wants to 'stop the water' (field notes).

In the transcript above the play involves several children and takes quite a long time. During the water play no adults are involved, for example, to discuss with the children how they can invent a water stop or carry the water in some other way. The data consists of other examples where children play alone, for instance, when constructing a hut in the nearby forest or when two girls try to make a kite "which can fly high in the sky". These observations show that free play with technology content is often carried out by the children themselves 
and when they play they interact with peers in order to solve different problems or to develop an idea they collectively formulated. In these kinds of situations the teachers are often not very active, which may be detrimental for children's learning in technology. When teachers support and scaffold the children in their free play, on the other hand, there is a greater potential for learning, for example, about using objects as tools.

\section{Discussion}

The starting point for this study is that technology education is a new learning area in the Swedish preschool at the same time as gender stereotypes should be counteracted (Skolverket, 2010; SOU 2006:75), which earlier research shows is a difficult balancing act. The empirical material is limited but despite this there are interesting findings which are well worth discussing and investigating further. In this section we will discuss some crucial aspects of how girls and boys explore and learn technology in free play in the two studied Swedish preschools. First we look at how boys and girls manage technology and their different technological vocabularies, and second, we focus on the relation to and role of the teachers. As a general conclusion we can say that the notion of childish technology is a relevant description of what happens in the free play since particularly the older children make sense of their relation to technology mainly in ways that they have to make up themselves; the teachers frame this sense-making by being more or - most often - less active and generally not so gender-conscious (Koch et al, 2011).

We can see in our observations that the girls handle technology in a different way compared to the boys. The girls more often have a special purpose in building something they need in their play. If we use Mitcham's (1994) concepts, they mostly engage in technological constructing activities as a sideline and use technological objects as an auxiliary in their play. It is conceivable that technology is seen as part of a broader social context of play, thereby making the construction in itself less interesting (cf. Mawson, 2010, p. 3-8). The boys, on the other hand, more often award the technological activities of constructing and of using various objects a central part in their play. In Mitcham vocabulary the boys engage the most in technological activities which are enough in themselves. We can consequently conclude that boys are more active in building and constructing as an activity in its own right in their free play compared to girls. Technology represents, communicates and translates knowledge in relation to both these practices, which means that girls and boys learn to internalize these different approaches to technology and thereby pass down and reinforce gender differences in relation to technology (Freeman, 2007; Koch et al, 2011; Mitcham, 1994, p. 154-160). 
There is also a difference between boys and girls when they use technology as some boys employ specific words belonging to a technical vocabulary in their process of building. They seem more familiar with using words that belong to a technological sphere, for example, 'drill pin' or 'we must construct a strong road so that the cars can drive on it without breaking it.' From a socio-cultural point of view, naming and terms used, e.g. of parts or tools, are intellectual means for learning for the children (Resnick et al, 1997; Schoultz et al, 2001), something which seems to be restricted to the boys.

To the extent that the teachers support the children, they encourage boys' use of technology in one way and girls' use in another. However, the older children who use technology in free play often get little or no support from the teachers in developing this use, and likewise those who do not handle technology or construct at all are not encouraged to do so. Thulin (2011) points to a similar situation in Swedish preschool science education, where children are often left to 'discovery learning' on their own. Parker-Rees (1997) and Milne (2013), for instance, are of the view that free play will stimulate design capabilities but the data from these Swedish preschools show that there is a downside when the play is too free. It may lead to a preschool environment in which the teachers let the children choose entirely freely and thereby those who do not choose to play with technology also miss the chance of developing knowledge in and about technology. That this situation has arisen is not very surprising since the in-service education that the teachers have taken part in has been focused on more experimental aspects of technology, for instance, how to make things float, but they have not received any education about supporting technology in free play, how to handle gendered behaviour in relation to technology, etc.

In the interviews some teachers said that they could see no gender differences at all, whereas some expressed awareness of the different ways boys and girls approach technology. This mixed understanding of gender on the part of the teachers presumably makes it difficult for them to frame free play activities where there are equal opportunities for both sexes (Turja et al, 2009; Mawson, 2010). Ironically, the very broad notion that 'everything is technology', which is sometimes taught in certain in-service education but is contrary to much modern research in the philosophy of technology (see e.g. Mitcham, 1994; de Vries, 2005; Arthur, 2009), opened up the possibility for certain teachers to see that not only boys but also girls handle technology in their daily lives.

The pedagogical problem that girls and boys learn to approach and handle technology differently remains, however, thereby confirming rather than dissolving gender boundaries. It is conceivable that technology in itself in the form of gendered toys and material contributes to and consolidates gender differences in the absence of clear pedagogical strategies on the 
part of the teachers. Kranzberg (1986) claims that 'technology is neither good nor bad; nor is it neutral' (p. 545). Far from being neutral, in the two preschools with an already gendered social environment technology therefore reinforces and petrifies gender stereotypes. This is a notable difference to Ärlemalm-Hagsér \& Pramling Samuelsson (2009) who found that children in some Swedish preschools also sometimes transcend traditional gender boundaries, for example, when playing with Lego blocks, although this was still quite uncommon.

\section{Future research and pedagogical implications}

In conclusion it seems as though the dilemma we had as a starting point is very much present even in this study, that is, the children aged three to six years old in our data largely reinforce gender differences when exploring and learning about technology in free play by themselves. Therefore, future research should have a look at the previous teaching that may have led to this situation. This would concern not only the preschool environment more generally but also the understanding and confidence of the teachers as well as the way in which the children have been taught and the activities that they have previously undertaken in relation to gender and technology. The parents may also have influenced the way the children relate to technology and gender, something which was apparent in, for instance, Freemans (2007) study, and would consequently also merit further investigation.

As regards pedagogical implications, it is crucial for the preschool teachers to gain a deeper understanding of both gender and technology, not the least the fact that the play should be, in MacNaughton's (2006) words, 'pleasurable' (p. 130) in relation to gender. Gender equality must be something the children like to do, particularly in the Swedish tradition of far-reaching freedom in the play. With this knowledge teachers can help especially the older children in choosing various activities, and support them in their process of learning about technological objects and activities that are not typically associated with their respective gender. In-service education needs to address not only experiments and construction but also gender issues and how teachers can create equal opportunities for boys and girls in the free play. Only then can Swedish preschools teach integrated, emancipatory childish technology.

\section{Acknowledgements}

This work was financed by the Swedish National Agency for Education (Skolverket) and CETIS, Centre for School Technology Education, to which the authors are grateful for support. 


\section{References}

Alderson, P. (2000). School student's views on school councils and daily life at school. Children \& Society, 14:121-134.

Arthur, W.B. (2009). The Nature of Technology: What It Is and How It Evolves. New York: The Free Press.

Axell, C. (2013). Teknikundervisningen i förskolan: En internationell utblick. Linköping: Forum för ämnesdidaktik, Linköping University.

Benson, C. \& Lunt, J., Eds. (2011). International Handbook of Primary Technology Education: Reviewing the Past Twenty Years. Rotterdam: Sense Publishers.

Bryman, A. (2001). Social Research Methods. Oxford: Oxford University Press.

Carr, M. (2000). Technological Affordance, Social Practice and Learning Narratives in an Early Childhood Setting. International Journal of Technology and Design Education, 10, 6179.

Charmaz, K. (2006). Constructing grounded theory: a practical guide through qualitative analysis. London: SAGE.

Corsaro, W.A. (2003). We're friends, right? Inside kids' cultures. Washington, D.C.: Joseph Henry Press.

de Vries, M. (2005). Teaching About Technology: An Introduction to the Philosophy of Technology for Non-Philosophers. Dordrecht: Springer.

Elvstrand, H., Hellberg, K. \& Hallström, J. (2012). Technology and Gender in Early Childhood Education: How Girls and Boys Explore and Learn Technology in Free Play in Swedish Preschools. In T. Ginner, J. Hallström \& M. Hultén (Eds.), Technology Education in the 21st Century: the PATT 26 Conference Stockholm, Sweden, 26-30 June 2012. Linköping: Linköping University Electronic Press.

Fleer, M. (1992). Introducing Technology Education to Young Children: A Design, Make and Appraise Approach. Research in Science Education, 22:132-139.

Fleer, M. (1999). The science of technology: Young children working technologically. International Journal of Technology and Design Education, 9, 269-291. 
Fleer, M. (2000). Working Technologically: Investigations into How Young Children Design and Make During Technology Education. International Journal of Technology and Design Education, 10:43-59.

Freeman, N.K. (2007). Preschoolers' perceptions of gender appropriate toys and their parents' beliefs about genderized behaviors: Miscommunication, mixed messages, or hidden truths? Early Childhood Education Journal, 34(5), 357-366.

Hammersley, M. \& Atkinson, P. (1995). Ethnography. Principles in practice. London: Tavistock.

Hope, G. (2000). Beyond their Capability? Drawing, Designing and the Young Child. The Journal of Design and Technology Education, 5(2): 106-114.

James, A. \& Prout, A. (1990). Constructing and reconstructing childhood: Contemporary issues in the sociological study of childhood. London: Falmer Press.

Koch, G., Sørensen, E. \& Levidow, L. (2011). Childish Science: Editorial Introduction. Science as Culture, 20(4):421-431.

Kranzberg, M. (1986). Technology and history: "Kranzberg's laws". Technology and Culture, 27(3), 544-560.

Löfdahl, A. (2002). Förskolebarns lek. En arena för kulturellt och socialt meningsskapande. Karlstad: Karlstad University.

MacNaughton, G. (2006). Constructing gender in early-years education. In C. Skeleton, B. Francis \& L. Smulyan (Eds.), The Sage Handbook of Gender and Education. Thousand Oaks, CA: Sage Publications.

Mawson, B. (2007). Factors Affecting Learning in Technology in the Early Years at School. International Journal of Technology and Design Education, 17:253-269.

Mawson, B. (2010). Children's Developing Understanding of Technology. International Journal of Technology and Design Education, 20:1-13.

Milne, L. (2013). Nurturing the designerly thinking and design capabilities of five-year-olds: technology in the new entrant classroom. International Journal of Technology and Design Education, 23:349-360.

Mitcham, C. (1994). Thinking through Technology. The Path between Engineering and Philosophy. Chicago and London: The University of Chicago Press. 
Parker-Rees, R. (1997). Learning from play: design and technology, imagination and playful thinking, IDATER 1997 Conference. Loughborough: Loughborough University, p. 20-25, http://hdl.handle.net/2134/1458.

Pearson, G. \& Young, A. T. (Red.). (2002). Technically speaking: Why all Americans need to know more about technology. Washington, D.C.: National Academy Press.

Prout, A. \& James, A. (1997). A new paradigm for the sociology of childhood? Provenance, promise and problems. In A. James \& A. Prout, Constructing and reconstructing childhood (pp. 7-33). London: Falmer Press.

Resnick, L.B., Säljö, R., Pontecorvo, C. \& Burge, B. (Eds.) (1997). Discourse, Tools, and Reasoning: Essays on Situated Cognition. Berlin: Springer.

Roberts, H. (2008). Listening to children and hearing them. In P. Christensen \& A. James (Eds.), Research with children: Perspective and practice. London: Falmer Press.

Schoultz, J., Säljö, R., \& Wyndhamn, J. (2001). Heavenly Talk: Discourse, Artifacts, and Children's Understanding of Elementary Astronomy. Human Development, 44, 103-118.

Skogh, I.-B. (2001). Teknikens värld - flickors värld. En studie av yngre flickors möte med teknik i hem och skola. Stockholm: HLS förlag.

Skolverket. (2010). Läroplan för förskolan, Lpfö 98 (reviderad 2010). Stockholm.

SOU 2006:75, Slutbetänkande av Delegationen för jämställdhet i förskolan, Jämställdhet $i$ förskolan - om betydelsen av jämställdhet och genus i förskolans pedagogiska arbete. Stockholm: Regeringskansliet.

SOU 2010:28, Teknikdelegationens betänkande Vändpunkt Sverige - ett ökat intresse för matematik, naturvetenskap, teknik och IKT. Stockholm: Regeringskansliet.

Stables, K. (1997). Critical issues to consider when introducing technology education into the curriculum of young learners. Journal of Technology Education, 8(2), 50-66.

Sullivan, A. \& Bers, M.U. (2013). Gender differences in kindergarteners' robotics and programming achievement. International Journal of Technology and Design Education, 23:691-702.

Thulin, S. (2011). Lärares tal och barns nyfikenhet: Kommunikation om naturvetenskapliga innehåll i förskolan. Göteborg: Göteborg University. 
Tu, T. (2006). Preschool Science Environment: What is Available in a Preschool Classroom? Early Childhood Education Journal, 33(4):245-251.

Turja, L., Endepohls-Ulpe, M. \& Chatoney, M. (2009). A Conceptual Framework for Developing the Curriculum and Delivery of Technology Education in Early Childhood. International Journal of Technology and Design Education, 19:353-365.

Vetenskapsrådet. 2013. Forskningsetiska principer inom humanistisk-samhällsvetenskaplig forskning. Stockholm: Vetenskapsrådet. http://www.codex.vr.se/texts/HSFR.pdf.

Ärlemalm-Hagsér, E. \& Pramling Samuelsson, I. (2009). Många olika genusmönster existerar samtidigt i förskolan. Pedagogisk forskning i Sverige, 14(2), 89-109. 